\title{
ASSESSMENT OF QUALITY AND SAFETY OF PORK TREATED WITH LOW-TEMPERATURE ATMOSPHERIC-PRESSURE PLASMA
}

Natalia Yu. Moskalenko', Olga A. Kudryashova², Leonid S. Kudryashov' Sergey L. Tikhonov ${ }^{1 *}$, Natal'ya V. Tikhonova ${ }^{1}$, Vladimir V. Pestov ${ }^{4}$

${ }^{1}$ Ural State Economic University, Ekaterinburg, Russia

${ }^{2}$ All-Russian Scientific Research Institute of Poultry Processing Industry -

Branch of the Federal State Budget Scientific Institution Federal Scientific Center "All-Russian Research and Technological Poultry Institute" of Russian Academy of Sciences, Rzhavki township, Moscow region, Russia

${ }^{3}$ V.M. Gorbatov Federal Research Center for Food Systems of Russian Academy of Sciences, Moscow, Russia ${ }^{4}$ FOTEK OOO, Ekaterinburg, Russia

Keywords: low-temperature plasma, argon plasma, microbial decontamination, meat, color, microbiological safety, storage periods, shelf life

\begin{abstract}
It is known that processing methods ensuring partial or full microbial inactivation are quite limited. Therefore, it is of great interest to develop technique and technologies allowing the effective action on microorganisms without a significant influence on product properties. The use of cold plasma can be one of the promising methods of meat product treatment by cold sterilization. The present work examines a possibility of chilled meat treatment with low-temperature atmospheric-pressure plasma to increase its stability to microbial spoilage and extend shelf life. To obtain low temperature plasma, the equipment developed by the designing department "Plasmamed" was used. Chilled meat was treated with low-temperature atmospheric-pressure argon plasma for 5, 10, 20 and $30 \mathrm{~min}$. Samples were stored at a temperature of $2-4{ }^{\circ} \mathrm{C}$ for 10 days. Organoleptic indices, moisture weight fraction, changes in $\mathrm{pH}$ and water activity were analyzed before treatment and during storage. Sanitary microbiological analyses were carried out by the following indicators: quantity of mesophilic aerobic and facultative anaerobic microorganisms (QMAFAnM), the presence and quantity of coliforms, Salmonella, Escherichia coli, Listeria monocytogenes, Proteus. It was shown that meat cold treatment with argon plasma inhibited the development of mesophilic microorganisms. The colony forming units detected in the samples after ten days of storage were determined by the duration of exposure to plasma. It was proved that meat treatment for 15 and 30 min had the bactericidal effect and facilitated an improvement in meat color during storage. The organoleptic indices of the samples treated with plasma corresponded to the requirements of standards and approved consumer characteristics.
\end{abstract}

\section{Introduction}

Modern food market conditions dictate a necessity to search for new approaches to their processing that would ensure high stability at storage and sales. A problem of preservation of non-treated food products (raw meat, chilled by-products, semi-finished products in pieces), in which possibilities of shelf life duration are limited, as a rule, by the use of packaging materials and gas atmosphere, has acquired special topicality. Modern packaging technologies are based on domination of the anabiosis principles - inhibition of microbial vital activities. Shelf life of products obtained using such methods is limited by the effectiveness of the microbial growth retardation and increase in duration of the lag-phase, during which microorganisms are not capable of significant damage to product safety and consumer characteristics due to their low concentration.

Immediately after production, meat raw materials with the intact structure are exposed only to surface contamination remaining practically sterile inside. Therefore, it can be expected that treatment of raw material surface based on abiosis principles will be significantly more effective regarding product safety.

From the practical point of view, realization of methods ensuring partial or almost full termination of vital activities in microbial cells is quite limited. Therefore, the studies aimed towards the development of equipment and technologies effectively influencing the condition of microflora without significant changes in the initial product properties are of particular interest. For these reasons, the electrophysical methods found application in the food industry.

Treatment with ultraviolet radiation (UV-radiation), ozone, gas atmosphere modified in the electrical field and some other bactericidal treatments are considered promising in regard to a decrease in product contamination and an increase in their storability $[1,2,3,4]$.

For example, Graça et al. [4] studied an effect of UV radiation on the yeast growth on fresh Royal gala apples stored at a temperature of $4{ }^{\circ} \mathrm{C}$. It was proved that treatment of apple samples contaminated with yeasts 
using ultra-violet radiation $\left(2.5-10 \mathrm{~kJ} / \mathrm{m}^{2}\right)$ reduced yeast growth rate by four times. UV radiation at doses of 7.5 and $10 \mathrm{~kJ} / \mathrm{m}^{2}$ showed the high bactericidal effect, which allowed preventing cross-contamination of food products with yeasts.

When studying UV treatment of chilled beef with and without ozone, the authors [5] found an effective reduction of meat microbial contamination during storage. In the experiments, meat was inoculated with cocktails of Shiga toxin-producing Escherichia coli (STEC) strains (serotypes O26, O45, O103, O111, O121, O145, and O157: H7), Salmonella, and Listeria monocytogenes. Then, inoculated beef was treated with UV radiation or UV radiation and ozone. The treatment reduced populations of $E$. coli O157: H7, Salmonella, L. monocytogenes, and aerobic bacteria from 1.49 to $0.86,1.33$ to $0.76,1.14$ to 0.5 , and 1.23 to $0.64 \log \mathrm{CFU}$, respectively. Gaseous ozone alone reduced populations of E. coli O157: H7, Salmonella, and L. monocytogenes by $0.65,0.70$, and $0.33 \log \mathrm{CFU}$, respectively. It was also found that exposure to UVC and ozone did not lead to noticeable changes in fresh meat color and did not accelerate the formation of products of oxidative and hydrolytic spoilage of the fat fraction of products, which indicates an expediency of using UV treatment including with the use of active gas atmosphere to enhance meat microbiological stability without deterioration of consumer characteristics.

Magnetic induction heating (MIH) is considered promising in regard to increasing microbiological safety of pasteurized products. In the study that compared the convective heating protocol and $\mathrm{MIH}$, death of Salmonella was achieved at temperatures of $60^{\circ} \mathrm{C}$ and $68^{\circ} \mathrm{C}$. Exposure to the alternating magnetic field (AMF) led to heat generation by microbeads with a size of about $50 \mu \mathrm{m}$ via the magnetic hysteresis effect, which later on ensured homogeneous product heating due to the high specific rate of heat distribution by homogeneous dispersed particles in highviscosity food products. Reduction of treatment duration allows preventing coagulation of egg proteins and ensures high preservation of the initial state of food nutrients [6,7].

It was proved in the study [8] of high pressure processing (HPP) of chicken meat in combination with active packaging based on an essential oil that the synergetic effect of applied impacts facilitated a reduction in the quantity of Listeria monocytogenes lower than the detection limit during 60 -day storage at low positive temperatures $\left(0^{\circ} \mathrm{C}\right.$ to $4^{\circ} \mathrm{C}$ ). However, the growth of L. monocytogenes began again when the temperature was increased up to $8^{\circ} \mathrm{C}$. The authors suggest that high pressure processing (HPP) of poultry meat can be beneficial for reducing the risk of raw material contamination with $L$. monocytogenes without deterioration of its quality.

The effectiveness of high pressure processing regarding the reduction of total aerobic and lactic acid bacteria counts in frozen beef was reported by Fernández et al. [9]. According to the authors' data, moisture losses upon thaw- ing and meat color were within limits comparable with those after thawing non-treated beef.

Undoubtedly, food sterilization with ionizing radiation is considered the most effective. Nowadays, however, this method is not accepted as safe. It was found that an ionizing radiation dose of $3 \mathrm{kGy}$ prevents the development of food microbiological spoilage during storage $[5,10]$.

Over the last years, new methods of thermal and nonthermal food processing have been designed, for example, ohmic heating, microwave treatment, high pressure processing, cold plasma, which turned to be less detrimental to processed food quality than traditional heating methods $[8,11]$.

The use of low-temperature atmospheric-pressure plasma (LTAP) is an innovative technology that envisages food processing with the ionized gas - cold plasma $[12,13]$. Ionization occurs due to an effect of an electric discharge emerged in the regulated conditions.

Multiple studies point to the high effectiveness of LTAP in regard to decontamination of different objects. The method of cold sterilization is widely used in processing medical instruments and materials $[14,15]$. The use of cold plasma in the food industry is introduced to a lower degree; however, the effectiveness of the bactericidal effect of LTAP on a wide range of causative agents of food spoilage has been studied and presented in literature quite extensive $[16,17,18]$.

The plasma composition and functionality significantly depend on ionization parameters - the voltage and frequency of an electric field, composition of a gas atmosphere and design of a generator. For example, cold plasma formed due to ionization of the atmospheric air is saturated with the reactive oxygen species (ROS) and reactive nitrogen species (RNS) that ensure the antimicrobial effect of treatment. Due to high temperatures, this technological gas can be used for simultaneous drying and microbial inactivation in free-flowing materials. Helium and argon plasmas have the effective antimicrobial activity. The peculiarity of inert gas ionization is their easy flammability [18].

An effect of a gas atmosphere on the reactivity of cold plasma is explained by non-uniformity of energy distribution between its particles due to differences in thermodynamic conditions of electrons and larger particles - ions and neutral molecules. Contrary to hightemperature plasma, the thermodynamic temperature of free electrons in cold plasma reaches tens of thousands of degrees Kelvin, while the temperature of molecules and ions is close to an ambient temperature. When colliding, free electrons transfer energy that leads to excitation of larger particles; however, a degree of reactivity remains non-uniform [19].

With respect to the use of cold plasma in the meat product technology, one of the most promising properties is its high electrical conductivity. The ability of the plasma medium to transfer charged particles under an effect of 
external electric fields, while at the same time retaining the ionized condition of the gas can be used for the development of methods for thermal food processing; however, it is not useful for preservation due to quick heating of a processed object.

An influence of design peculiarities of plasma generators (plasmatrons) is expressed in the possibility to realize different types of charges inducing plasma flows with different characteristics [20].

One of the main methods for generation of cold atmospheric-pressure plasma is a dielectric barrier discharge (DBD) emerging due to electrical breakdown between two electrodes under an impact of high pressure. At the moment of the discharge, high current is induced due to high breakdown conductivity; however, short exposure duration (8-10 s) does not allow inducing high amounts of energy (Figure 1A). As a rule, dielectric discharges emerge at alternating voltage in a frequency range of 50 to several thousands of Hz. Voltage varies from 1 to $100 \mathrm{kV}$ and more [20].

A dielectric barrier discharge has a low threshold of cold plasma ignition, and is characterized by a large area of impact, which makes it the most acceptable for product decontamination. The effectiveness of the DBD plasma treatment method was established with regard to eggs [21],

A packaging materials and packed foods including sausage products, packed fruit and vegetables [22,23]. Treatment of a product with a dielectric barrier discharge for $15 \mathrm{~s}$ fully inactivated microorganisms in a quantity of $10^{7} \mathrm{CFU} / \mathrm{g}$, while 2 -min treatment practically killed most pathogenic microorganisms [24].

Modification of the method for obtaining cold atmospheric-pressure plasma is generation of a discharge in a frequency range from several $\mathrm{kHz}$ to tens of $\mathrm{MHz}$ and power from several $\mathrm{W}$ to $\mathrm{kW}$ in the dielectric tube (Figure 1B) [25]. The generated electric discharge runs out of the tube with the flow of ionized gas forming plasma jets. Characteristics of plasma jets depend on the type of electrode location and parameters of power supply (Figure 2).

This method is the prevalent source of low-temperature plasma. However, to ensure high performance of the generator that is sufficient for treatment of large areas, the simultaneous impact of several jets is necessary. It should be noted that the high plasma concentration in the jet conditions ensures effectiveness of antimicrobial treatment [26].

There is a method of microwave plasma striking. Microwave discharges at atmospheric pressure usually are plasma torches that work with large gas flows similar to plasma jets (Figure 1C). Flares induce plasma at a frequen-

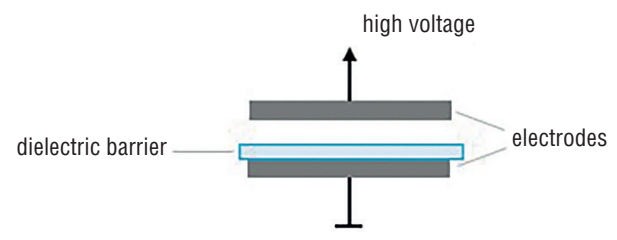

B

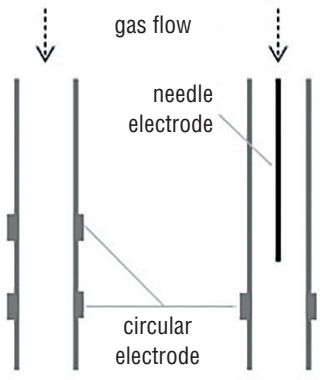

C

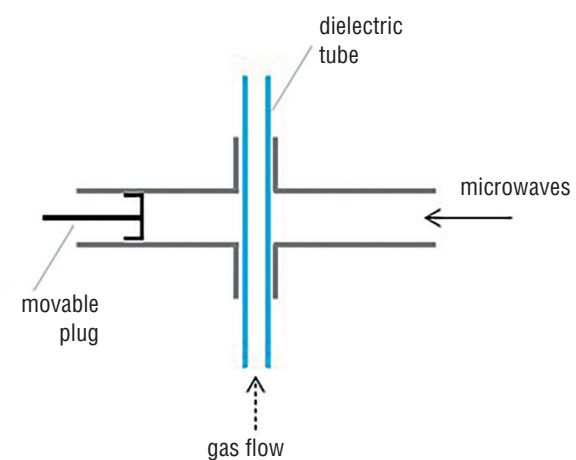

Figure 1. Schematic illustration of (A) the dielectric barrier discharge, (B) different units for plasma jets and (C) simplified microwave plasma torch

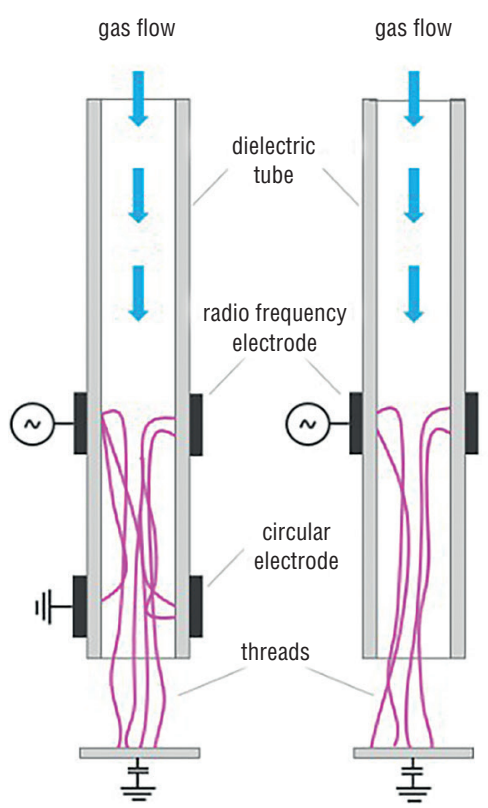

Figure 2. Configuration of electrodes
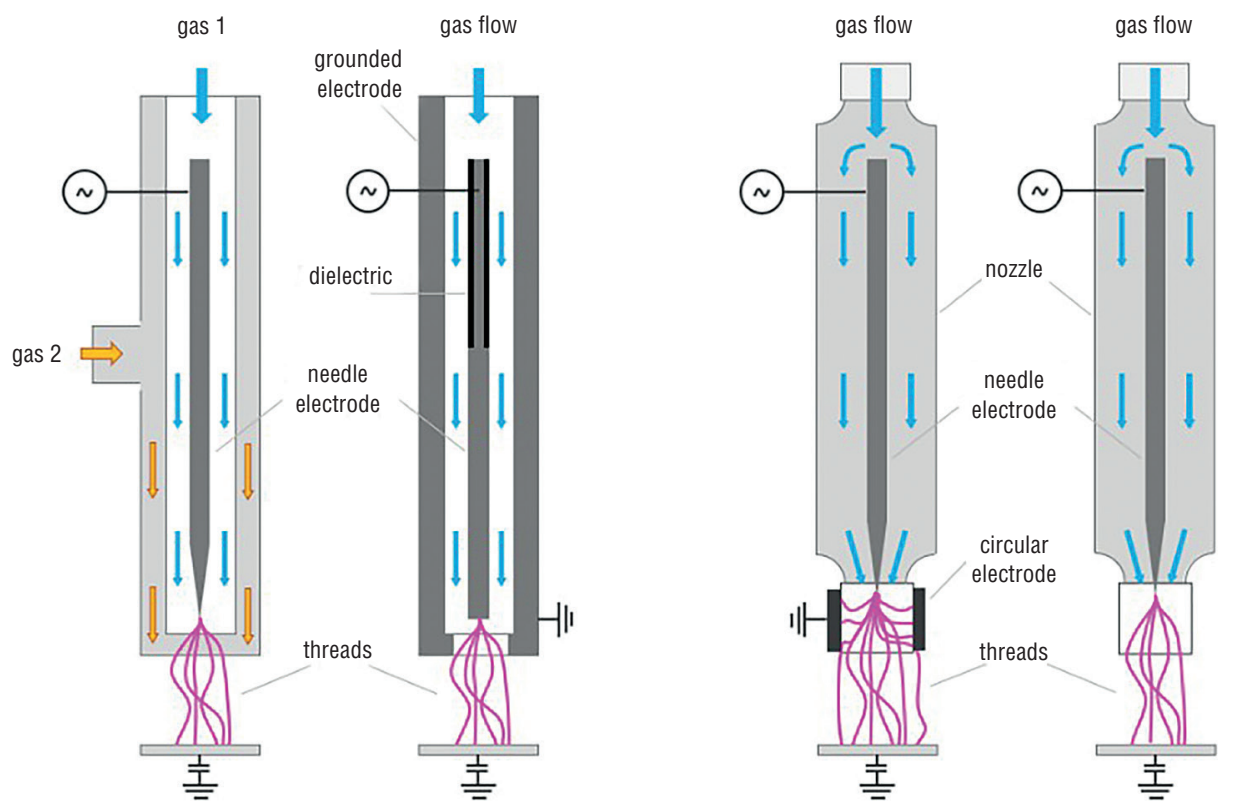
cy from several $\mathrm{GHz}$ in a power range from $10 \mathrm{~W}$ to about 6 $\mathrm{kW}$. However, the plasma gas is heated in these conditions, which is a significant limitation for using this method for food processing.

Summarizing an experience in sterilization of different objects, the authors [17] propose to use several plasma sources (microplasma matrices, surface and coplanar dielectric barrier discharge) as a promising technology.

To use plasma in the food industry, its temperature should not exceed $20^{\circ} \mathrm{C}$ to avoid denaturation changes in protein and induction of oxidative processes. When processing thermosensitive food products, the necessary plasma temperature is achieved mainly by regulation of the ionizing gas composition. Differences in the thermodynamic condition of electrons, ions and molecules, non-uniformity of energy distribution upon their collision and, as a consequence, changes in a plasma temperature can be managed by the composition of the initial gas atmosphere [27,28].

Wang et al. [29] stated that cold plasma processing of food products is regarded as promising sterilization technology. At the same time, studies on inactivation of microbial cells in solutions are practically absent. It was proved in the experiments with a computer simulation model of a plasma reactor that high background concentration of yeasts negatively affected their inactivation.

Sahebkar et al. [30] presented the study on an effect of cold plasma treatment of marinades, which were injected into chicken fillets infected with Escherichia coli and Staphylococcus aureus, on microbial contamination of the product. The study proved a decrease in the growth of the above mentioned microorganisms.

Another important aspect of food treatment with ionized low-temperature plasma is a method of its contact with the object surface. Contact of the plasma gas and a product can be considered most effective; as a result, many reactive compounds directly affecting microorganisms are concentrated on the treated surface [31]. The mechanism of the bactericidal effect of low-temperature plasma is similar to ultraviolet radiation, which has the high penetrating ability and causes the death of a microbial cell linked with destruction of the DNA structure [32]. UV radiation weakens DNA replication process and, thus, hinders microbial multiplication [33]. Effectiveness of UV radiation range $(200-220 \mathrm{~nm})$ is linked with the fact that maximum inactivation of the cell genetic composition is achieved under the action of short-wave radiation. It is necessary to note that only $7 \%$ of low-temperature plasma action occur in the above mentioned wavelength range. With that, however, plasma has the high bactericidal effect, which to a large extent is conditioned by the intensity within this particular wavelength range, where the maximum inactivation of microbial DNA takes place. Moreover, the bactericidal action of plasma is enhanced due to food treatment throughout the whole volume and the development of pulse-periodic electric discharges within food systems $[34,35]$.

The aim of this research was to study a possibility of using the equipment for low-temperature plasma generation in the conditions of atmospheric pressure developed by the designing department "Plasmamed" [36] (hereafter, plasmatron) for treatment of chilled meat to increase its storability at low positive temperatures.

\section{Materials and methods}

M. longissimus dorsi from chilled pork produced by Rodnikovsky pig-breeding farm (Chelyabinsk Oblast, Miasskoye settlement) was chosen as an object of research. During the experiments, the following samples were made: 1 - control; $2 \div 5$ - experimental samples treated for 5, 10, 20 and 30 minutes on the plasmatron under the same conditions of plasma generation (Figure 3). The weight of samples was $1.5-1.6 \mathrm{~kg}$; sizes were $16 \mathrm{~cm} \times 22 \mathrm{~cm} \times 10 \mathrm{~cm}$; a temperature of the samples before the experiment was $4^{\circ} \mathrm{C}$.

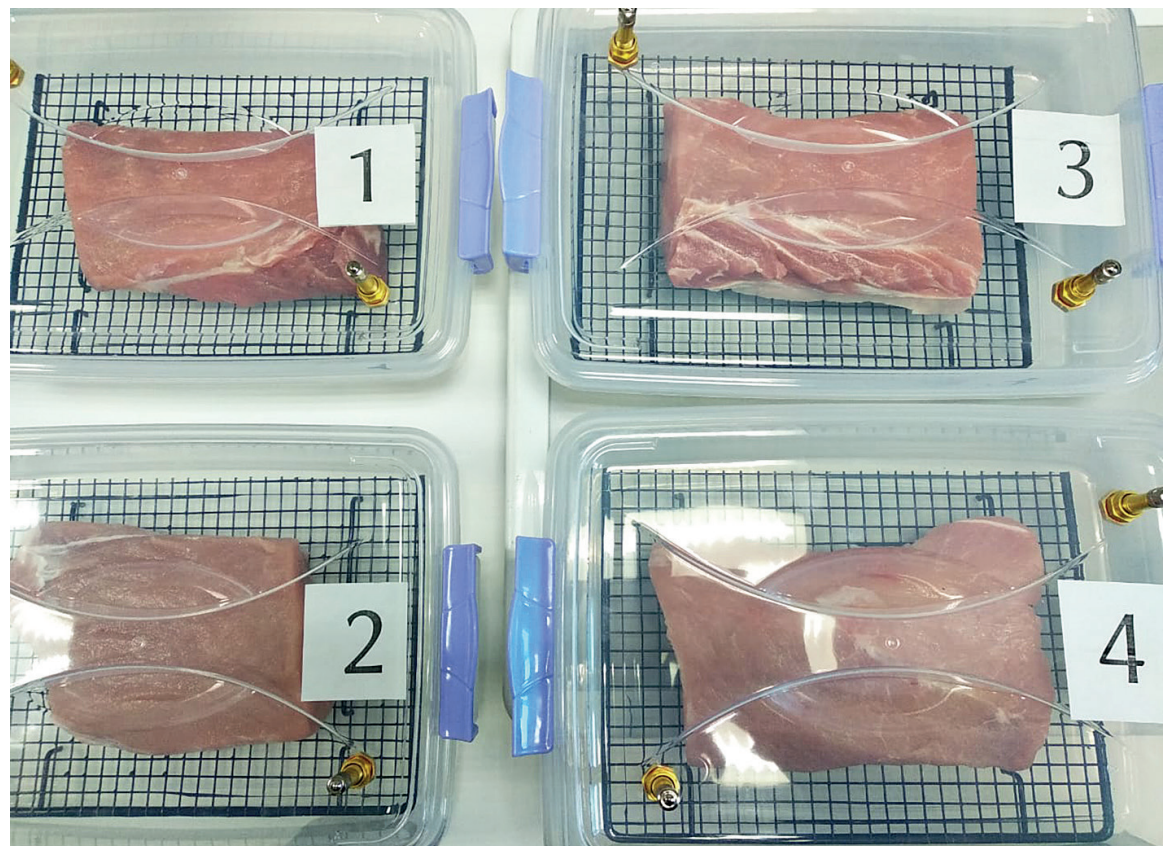

Figure 3. Chilled meat samples for analyses 


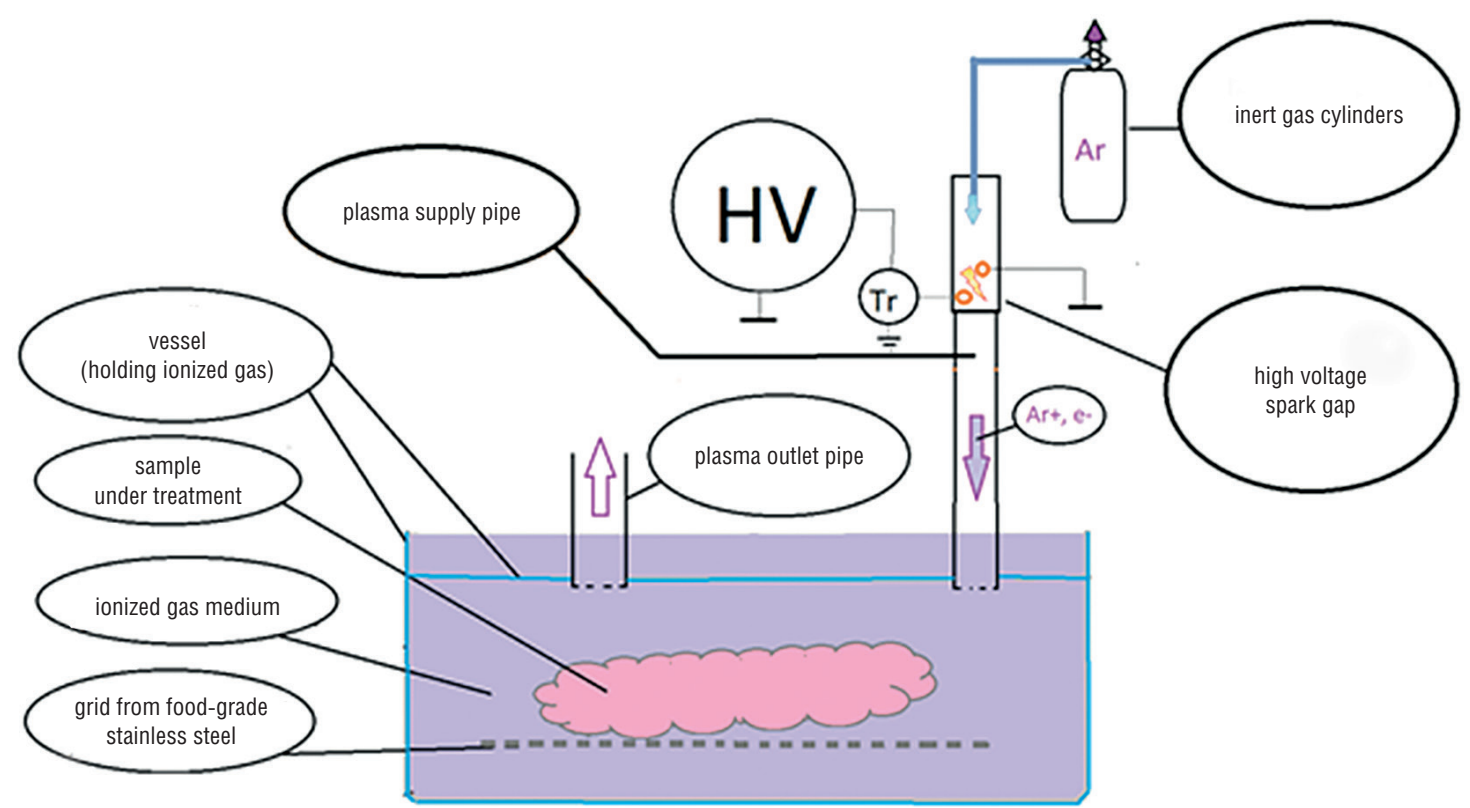

Figure 4. Scheme of meat treatment with low-temperature atmospheric-pressure argon plasma

To create a modified atmosphere, inert gas argon ${ }^{1}$ was used, which ionization took place in the working chamber of the plasmatron using the DBD method under the impact of discharges with frequencies of 450 to $550 \mathrm{kHz}$ induced by the current supplied to the electrodes. The voltage between electrodes was $12-14 \mathrm{kV}$, the power of the generator was $25-30 \mathrm{~W}$.

The principal scheme of the developed equipment for chilled meat treatment with low-temperature atmospheric-pressure argon plasma is presented in Figure 4.

In the experiment, meat was placed unpacked into 3 L plastic containers with lids fitted with valves for supplying and removing modified atmosphere (Figure 3). To control a level of air replacement in a container with the ionized gas, the outlet pipe was fitted with a bag, which volume corresponded to the volume of the container. When plasma was supplied, air was displaced from the container into the bag. After filling the container, the bag was detached, the exhaust valve was closed and the ionized plasma gas continued to be supplied to the container. Treatment time was recorded for each sample using a timer with the accuracy of up to $5 \mathrm{~s}$. After treatment, containers with the samples were placed into a refrigerator chamber for storage at a temperature of $2{ }^{\circ} \mathrm{C} \ldots 4^{\circ} \mathrm{C}$.

An effect of treatment on meat preservation in the chilled condition was assessed according to the recommendation ${ }^{2}$ by the scheme for products with expected shelf-life up to 10 days in the test-laboratory SBI of the Sverdlovsk Region "Sverdlovsk Regional Veterinary Laboratory". Sanitary microbiological analyses were carried out by the following indicators: quantity of mesophilic aerobic and

${ }^{1}$ GOST 10157-2016 "Gaseous and liquid argon. Specifications". — Moscow: Standartinform. 2019. - 27 p.

${ }^{2}$ MUK 4.2.1847-04. Sanitary and epidemiological assessment of the validity of shelf life and storage conditions of food products. - Moscow: Minzdrav RF. $-32 \mathrm{p}$. facultative anaerobic microorganisms (QMAFAnM) $)^{3}$, the presence and quantity of coliforms ${ }^{4}$, Salmonella ${ }^{5}$, Escherichia coli ${ }^{6}$, L. monocytogenes ${ }^{7}$, Proteus $^{8}$. Organoleptic indices $^{9}$ and moisture weight fraction ${ }^{10}$ were determined in the plasma treated and control samples. The $\mathrm{pH}$ indicator was determined by the potentiometric method using a digital $\mathrm{pH}$-meter (model 2696) with a measurement range of 0-14 $\mathrm{pH}$ units and the measurement accuracy of $0.05 \mathrm{pH}$ units. Water activity (aw) in the initial samples and after storage was recorded using a water activity analyzer AWC- 4 with a measurement range of 1.00 to 0.75 with the measurement accuracy of 0.0001 units with the computer communication interface.

\section{Results and discussion}

Organoleptic indices in the samples were analyzed before their treatment and controlled every day of the following storage. At the initial stage, all muscles had similar condition and were scored identically. After a day of storage at low positive temperatures, the samples treated with plasma differed from the control by more intensive surface color; with that, the color intensity in the samples increased with

\footnotetext{
${ }^{3}$ GOST 10444.15-94. "Food products. Methods for determination of quantity of mesophilic aerobes and facultative anaerobes". - Moscow: Standartinform. 2010. $-7 \mathrm{p}$.

${ }^{4}$ GOST 31747-2012. "Food products. Methods for detection and quantity determination of coliforms". - Moscow: Standartinform. 2010. - 27 p.

${ }^{5}$ GOST R50455-92 (ISO 3565-75) ."Meat and meat product. Detection of salmonellae (Reference method)".. - Moscow: Standartinform. 2010. - 14 p.

${ }^{6}$ GOST R50454-92 (ISO 3811-79). "Meat and meat products. Detection and enu-meration of presumptive coliform bacteria and presumptive Escherichia coli (Reference method)". - Moscow: Standartinform. 2010. - 8 p.

${ }^{7}$ GOST 32031-2012. "Food products. Methods for detection of Listeria monocytogenes". - Moscow: Standartinform. 2014. - 29 p.

${ }^{8}$ GOST 28560-90. "Food products. Method for detection of bacteria of Proteus, Morganella, Providencia genera". - Moscow: Standartinform. 2010. - 7 p.

${ }^{9}$ GOST 9959-2015. "Meat and meat products. General conditions of organoleptical assessment". - Moscow: Standartinform. 2016. - 24 p.

${ }^{10}$ GOST 33319-2015. "Meat and meat products. Method for determination of moisture content". - Moscow: Standartinform. 2018. - 9 p.
} 
Table 1. Physico-chemical indicators of the control and experimental samples of chilled pork before and after storage

\begin{tabular}{|c|c|c|c|c|c|c|c|c|c|c|c|}
\hline \multirow{3}{*}{\multicolumn{2}{|c|}{ Indicator }} & \multirow{2}{*}{\multicolumn{2}{|c|}{ Control samples ${ }^{3)}$}} & \multicolumn{8}{|c|}{ Samples treated with argon LTAP (duration in min.) before and after storage } \\
\hline & & & & \multicolumn{2}{|c|}{5} & \multicolumn{2}{|c|}{10} & \multicolumn{2}{|c|}{20} & \multicolumn{2}{|c|}{30} \\
\hline & & before & after & before & after & before & after & before & after & before & after \\
\hline \multicolumn{2}{|c|}{$\mathrm{pH}$} & 5.72 & 5.86 & 5.67 & 5.74 & 5.85 & 5.91 & 5.76 & 5.82 & 5.77 & 5.84 \\
\hline \multirow{2}{*}{$\mathrm{W}^{1)}, \%$} & $S^{2)}$ & - & - & 53.67 & 51.43 & 54.16 & 52.98 & 55.15 & 53.02 & 55.19 & 53.54 \\
\hline & $\mathrm{C}^{2)}$ & 54.33 & 54.21 & 53.95 & 53.42 & 53.89 & 53.27 & 54.68 & 53.88 & 54.62 & 54.07 \\
\hline \multirow{2}{*}{ a } & $\mathbf{S}^{2)}$ & - & - & 0.9860 & 0.9839 & 0.9882 & 0.9827 & 0.9864 & 0.9811 & 0.9825 & 0.9816 \\
\hline & $\mathrm{C}^{2)}$ & - & - & 0.9887 & 0.9874 & 0.9864 & 0.9849 & 0.9844 & 0.9844 & 0.9854 & 0.9841 \\
\hline
\end{tabular}

1) W - moisture weight fraction;

2) $\mathrm{S}$ - for samples taken from the surface layer with a thickness of not more than $3 \mathrm{~mm}$;

$\mathrm{C}$ - for samples taken from the central part of meat;

3) After 5 days of storage.

increasing treatment duration. The revealed differences in the color intensity remained up to the sixth day of storage. During following storage, differences in the color intensity in the treated samples were not significant; the samples had the dark pink color.

When storing non-treated pork, the surface color intensity insignificantly grew; however, the color remained to be paler compared to plasma treated samples. After six days of storage, organoleptic traits of spoilage began to appear in the control sample as moisturization and weak discoloration of the surface.

An effect of storage on the color intensity in the LTAP treated samples can be explained by a change in the condition of the meat surface layer due to partial drying, and, probably, due to more intensive and directed transformation of heme pigments with prevalence of oxyforms.

Organoleptic analyses of the experimental samples during and after storage did not reveal significant differences in appearance, consistency and odor. Signs of spoilage were not found.

The values of $\mathrm{pH}$, moisture weight fraction (W) and water activity $\left(\mathrm{a}_{\mathrm{w}}\right)$ determined in the surface layer with a depth of not more than $3 \mathrm{~mm}(\mathrm{~S})$ and in the samples from the meat center $(\mathrm{C})$ before treatment and after 10 days of storage are presented in Table 1.

It was established that meat storage in containers without additional packaging led to some weight losses due to moisture removal mainly from the surface layer. By the end of storage, the value of moisture weight fraction in the surface layer of the experimental samples decreased on average by $3.30 \pm 0.87 \%$ relative to the value in the surface layer of the samples sent to storage. Moisture of the surface samples and the samples taken from the central layers of meat before storage did not have significant differences.

It is impossible to explain directly the observed reduction of moisture in the surface layer of the samples treated with LTAP by an effect of low-temperature plasma. However, it can be assumed that the sterilization effect of treatment significantly inhibits the microbial development on the meat surface. As a result of treatment, the concentration of the products of microbial vital activities also de- creased. These products facilitate moisturization and following slime formation on the surface, which was observed in the control sample after six days of storage.

The $\mathrm{pH}$ values in fresh and stored chilled meat were different by not more than 0.6 units, which is a consequence of the biochemical changes in chilled muscle tissue during storage and indirectly confirm the absence of intense microbial growth.

The water activity values correlate with the data on the moisture content.

The results of the microbial analyses are of critical importance for assessment of the LTAP effect on meat storability. The control and plasma treated samples were analyzed after five and ten days of storage, respectively.

According to the results of the investigation, L. monocytogenes, Salmonella, Proteus, E.coli were not detected. Changes were noted in QMAFAnM values and the presence of coliforms. The results of the experiments are given in Table 2.

Table 2. QMAFAnM values and presence of coliforms in the samples after storage

\begin{tabular}{|c|c|c|}
\hline \multirow{2}{*}{ Samples } & \multicolumn{2}{|c|}{ Value of the indicator } \\
\cline { 2 - 2 } Control & $\begin{array}{c}\text { QMAFAnM, not more } \\
\text { than, CFU/g }\end{array}$ & Coliforms \\
\hline & $\begin{array}{c}7.4 \cdot 0^{5} \\
\text { Обработанные НПАД, мин }\end{array}$ & Detected in $\mathbf{~ g}$ \\
\hline 5 & $\mathbf{6 . 0 \cdot 1 0 ^ { 5 }}$ & Not detected \\
\hline 10 & $5.1 \cdot 10^{3}$ & Not detected \\
\hline 30 & $3.1 \cdot 10^{3}$ & Not detected \\
\hline
\end{tabular}

According to the obtained data, treatment of chilled meat with argon plasma inhibits the development of mesophilic microorganisms. It was established that the colony forming units detected in the samples after ten days of storage depended on the duration of exposure to plasma. Comparison of the obtained values with the data from literature sources [37] confirmed the high potential of meat treatment in the flow of argon plasma to preserve chilled products. 
The obtained results on the reduction of bacterial contamination of chilled meat after treatment with cold atmospheric-pressure plasma correspond to the study [38], which linked the plasma effect with an impact on cellular DNA. One of the mechanisms of microbial cell destruction is breakage and modification of cellular DNA. Another one is dimerization of thymine and oxidation of bases in the DNA composition with formation of 8-OHdG in prokaryotic cells under the impact of cold plasma. Reparation of DNA damages or cell death was initiated depending on a damage degree.

There are also other theories that explain mechanisms of the bactericidal effect of cold plasma on a microbial cell.

According to study [39], nitrogen reactive species can accumulate on the surface of microbial cells and easily diffuse through cell membranes causing a decrease in the intracellular $\mathrm{pH}$. This indicator plays an important part in cell functioning. It affects the enzyme activity, rate of reaction, protein stability and nucleic acid structure. A decrease in the intracellular $\mathrm{pH}$ causes destruction of the microbial cells. It was established in our investigations that an increase in the time of meat treatment with cold plasma insignificantly influenced microbial contamination, which corresponds to data [40]. The authors also did not reveal a significant effect of the treatment duration on microbial deactivation. At the same time, repetition of ten-minute treatment of meat products with cold plasma increases the intensity of microbial inactivation, which depends not only on conditions of plasma treatment but also on a food product type and, in particular, on characteristics of their surfaces. It is always necessary to take into account this factor when choosing parameters for effective microbial inactivation.

In our investigations, meat samples were treated throughout the whole area, which allowed inactivation of most microorganisms and corresponds to the results of study [41]. The authors state that two-sided treatment of chicken breasts during $2.5 \mathrm{~min}$ facilitated deeper microbial inactivation than one-sided treatment for $5 \mathrm{~min}$. Similar conclusions were also obtained for pork loins. According to investigations, food product treatment with oxygen atmospheric-pressure plasma enhances the intensity of UV radiation. UV photons and particles reactivated in plasma enhance its bactericidal action. Based on the obtained results, the authors emphasize the necessity of the careful approach when applying longer product treatment with plasma as their organoleptic indicators can change. Taking into account our own results and opinions of foreign researchers, we recommend chilled meat treatment with LTAP for $20 \mathrm{~min}$.

When studying an effect of helium and argon plasma on microbiota of the pork and beef surface, the authors [42] established that 10-min treatment with helium plasma led to reduction of the total microbial count, the number of yeasts and psychrotrophic microorganisms by 1.14-1.48 log cycles for pork and 0.98-2.09 log cycles for beef. More significant reduction of microbial counts by $2.00 \mathrm{log}$ cycles was observed for Bacillus subtilis and Yersinia enterocolitica after 2 min of helium plasma treatment. Similar results were established for Staphylococcus aureus, E. coli and Pseudomonas fluorescens after $5 \mathrm{~min}$ and $10 \mathrm{~min}$ of exposure. Disruption and lysis of E. coli cells treated with helium plasma for $10 \mathrm{~min}$ were revealed. The presented data about the effectiveness of contaminated meat treatment with low-temperature plasma correspond to our results.

Ulbin-Figlewicz et al. [43] studied an effect of cold plasma treatment on microbial inactivation of meat surface, meat color and $\mathrm{pH}$ value. Nitrogen, argon and helium plasmas generated by high voltage discharge in a vacuum chamber were used for the experiment. The final plasma pressure was $0.8 \mathrm{MPa}$; the exposure time of samples in the active medium was 5 and $10 \mathrm{~min}$. The authors proved that the number of psychrotrophic bacteria and total microbial counts on the surface of the samples treated with helium and argon plasmas for 10 min reduced by about $3 \log \mathrm{CFU} / \mathrm{cm}^{2}$ and $2 \log \mathrm{CFU} / \mathrm{cm}^{2}$, respectively. In addition, more intense reduction of yeasts and molds was revealed, which was about $3 \mathrm{CFU} / \mathrm{cm}^{2}$ and $2.6 \mathrm{CFU} / \mathrm{cm}^{2}$ for helium and argon plasma, respectively. Significant differences in the $\mathrm{pH}$ values before and after cold plasma treatment were not observed, which confirm the results of our investigations.

Our results obtained regarding an effect of treatment with low-temperature plasma on the moisture content in pork samples are in agreement with data of other researchers [44,45]. Assessment of cold atmospheric-pressure plasma effectiveness for inactivation of two bacterial pathogens and its effect on changes in the moisture content showed that treatment inactivated Staphylococcus aureus and L.monocytogenes, reduced yeast-mold counts, and led to reduction of the moisture content in a food product by $7.34 \%$ due to water evaporation from the sample surface.

The presented analysis of the data about an effect of plasma on microorganisms is confirmed by our data about changes in the water activity in plasma treated and nontreated pork samples, which also indirectly confirm an increase in meat microbiological stability and revealed a decrease in the moisture weight fraction in the surface layers of the studied objects.

\section{Conclusion}

The results of the microbiological investigations unambiguously suggest the inhibitory action of ionized argon produced in the unit for generation of low-temperature plasma of the designing department "Plasmamed" in regard to mesophilic microorganisms developing on the surface of chilled meat during storage. Meat holding in the ionized atmosphere under the accepted conditions significantly reduced QMAFAnM and had a detrimental effect on coliforms, which was confirmed by the water activity value before and after storage. The organoleptic in- 
dices of the plasma treated samples corresponded to the requirements of standards and conventional consumer characteristics.
The effect of argon plasma on color stability revealed during investigations should be further studied.

\section{REFERENCES}

1. Fouad M. Gaber, M. A., Knoerzer, K., Mansour, M. P., Trujillo, F. J., Juliano, P., Shrestha, P. (2020). Improved canola oil expeller extraction using a pilot-scale continuous flow microwave system for pre-treatment of seeds and flaked seeds. Journal of Food Engineering, 284, Article 110053. https://doi.org/10.1016/j. jfoodeng.2020.110053

2. Zhang, Y., Zhu, G., Li, X., Zhao, Y., Lei, D., Ding, G. at al. (2020). Combined medium- and short-wave infrared and hot air impingement drying of sponge gourd (luffa cylindrical) slices. Journal of Food Engineering, 284, Article 110043. https://doi. org/10.1016/j.jfoodeng.2020.110043

3. Wu, X., Wang, C., Guo, Y. (2020). Effects of the high-pulsed electric field pretreatment on the mechanical properties of fruits and vegetables. Journal of Food Engineering, 274, Article 109837. https: //doi.org/10.1016/j.jfoodeng.2019.109837

4. Graca, A., Santo, D., Pires-Cabral, P., Quintas, C. (2020). The effect of UV-C and electrolyzed water on yeasts on fresh-cut apple at $4{ }^{\circ} \mathrm{C}$. Journal of Food Engineering, 282, Article 110034. https://doi.org/10.1016/j.jfoodeng.2020.110034

5. Boillereaux, L., Curet, S., Hamoud-Agha, M. M., Simonin, H. (2013, 16-18 December). Model-based settings of a conveyorized microwave oven for minced beef simultaneous cooking and pasteurization. Paper presented at the IFAC Proceedings Volumes (IFAC-PapersOnline), Mumbai, India, 46(31 PART 1), 193198. https://doi.org/ 10.3182/20131216-3-IN-2044.00014

6. Jun, S., Yaoyao, M., Hui, J., Obadi, M., Zhongwei, C., Bin, X. (2020). Effects of single- and dual-frequency ultrasound on the functionality of egg white protein. Journal of Food Engineering, 277, Article 109902. https://doi.org/10.1016/j.jfoodeng.2020.109902 7. Andreou, V., Tsironi, T., Dermesonlouoglou, E., Katsaros, G., Taoukis, P. S. (2018). Combinatory effect of osmotic and high pressure process in on shelf life extensions animal origin products Application to child characteristics. Food Packaging and Shelf Life, 15, 43-51. https://doi.org/10.1016/j.fpsl.2017.11.002

8. Stratakos, A. C., Delgado-Pando, G., Linton, M., Patterson, M. F., Koidis, A. (2015). Synergism between high-pressure processing and active packaging against listeria monocytogenes in ready-to-eat chicken breast. Innovative Food Science and Emerging Technologies, 27, 41-47. https://doi.org/10.1016/j.ifset.2014.11.005

9. Fernández, P. P., Sanz, P. D., Molina-García, A. D., Otero, L., Guignon, B., Vaudagna, S. R. (2007). Conventional freezing plus high pressure-low temperature treatment: Physical properties, microbial quality and storage stability of beef meat. Meat Science, 77(4), 616-625. https://doi.org/10.1016/j.meatsci.2007.05.014 10. Apostolou, I., Papadopoulou, C., Levidiotou, S., Ioannides, K. (2005). The effect of short-time microwave exposures on escherichia coli 0157: $\mathrm{H} 7$ inoculated onto chicken meat portions and whole chickens. International Journal of Food Microbiology, 101(1), 105-110. https://doi.org/10.1016/J.ijfoodmicro.2004.10.043

11. Kalchayan, N., Bosilevac, J.M., King, D.A., Wheeler, T.L. (2020). Evaluation of UVC radiation and a UVC-ozone combination as fresh beef interventions against Shiga toxin-producing Escherichia coli, salmonella, and listeria monocytogenes and their effects on beef quality. Journal of Food Protection, 83(9), 15201529. https://doi.org/10.4315/JFP-19-473

12. Jung, S., Kim, H.J., Park, S., In Yong, H., Choe, W., Jo, C. (2015). The use of atmospheric pressure plasma-treated water as a source of nitrite for emulsion-type sausage. Meat Science, 108, 132-137. https://doi.org/10.1016/j.meatsci.2015.06.009

13. Moisan, M., Barbeau, J., Moreau, S., Pelletier, J., Tabrizian, M., Yahia, L'H. (2001). Low temperature sterilization using gas plasmas: A review of the experiments, and an analysis of the inactivation mechanisms. International Journal of Pharmaceutics, 226(12), 1-21. https://doi.org/10.1016/s0378-5173(01)00752-9 14. Laroussi, M. (2009). Low-Temperature Plasmas for Medicine? IEEE Transactions on Plasma Science, 37(6), 714-725. https://doi.org/10.1109/tps.2009.2017267

15. Fridman, G., Friedman, G., Gutsol, A., Shekhter, A.B., Vasilets, V.N., Fridman, A. (2008). Plasma Processes and Polymers, 5(6), 503-533. https://doi.org/10.1002/ppap.200700154
16. Akishev, Y., Grushin, M., Karalnik, V., Trushkin, N., Kholodenko, V., Chugunov, V., at al. (2008).Atmospheric pressure nonthermal plasma sterilization of microorganisms in liquids and on the surfaces. Pure and Applied Chemistry, 80(9), 1953-1969. https://doi.org/10.1351/pac200880091953

17. Kobzev, E.N., Kireev, G.V., Rakitskii, Y.A., Martovetskaya, I.I., Chugunov, V.A., Kholodenko, V.P. at al. (2013). Effect of cold plasma on the E. coli cell wall and plasma membrane. Applied Biochemistry and Microbiology, 49(2), 144-149. https://doi. org/10.1134/S0003683813020063

18. Akishev, Y., Trushkin, N., Grushin, M., Petryakov, A., Karal'nik, V., Kobzev, E., Kholodenko, V., et al. (2012). Inactivation of Microorganisms in Model Biofilms by an Atmospheric Pressure Pulsed Non-thermal Plasma. In: Machala Z., Hensel K., Akishev Y. (eds) Plasma for Bio-Decontamination, Medicine and Food Security. NATO Science for Peace and Security Series A: Chemistry and Biology. Springer, Dordrecht. https://doi.org/10.1007/978-94007-2852-3_12

19. Moritz, M., Wiacek, C., Koethe, M., Braun, P.G. (2017). Atmospheric pressure plasma jet treatment of Salmonella enteritidis inoculated eggshells. International Journal of Food Microbiology, 245, 22-28. https://doi.org/10.1016/j.ijfoodmicro.2017.01.004 20. Almeida, F.D.L., Cavalcante, R.S., Cullen, P.J., Frias, J.M., Bourke, P., Fernandes, F.A.N., Rodrigues, S. (2015). Effects of atmospheric cold plasma and ozone on prebiotic orange juice. In novative Food Science and Emerging Technologies, 32, 127-135. https://doi.org/10.1016/j.ifset.2015.09.001

21. Kogelschatz, U., Eliasson, B., Egli, W. (1999). From ozone generators to flattelevision screens: history and future potential of $\mathrm{di}$ electric-barrier discharges. Pure and Applied Chemistry, 71(10), 1819-1828. https://doi.org/10.1351/pac199971101819 22. Wan, Z., Chen, Y., Pankaj, S.K., Keener, K.M. (2017). High voltage atmospheric cold plasma treatment of refrigerated chicken eggs for control of Salmonella Enteritidis contamination on egg shell. LWT - Food Science and Technology, 76, 124-130. https://doi.org/10.1016/j.Iwt.2016.10.051

23. Misra, N.N., Moiseev, T., Patil, S., Pankaj, S.K., Bourke, P., Mosnier, J.P., Keener, K.M., Cullen, P.J. (2014). Cold plasma in modified atmospheres for post-harvest treatment of strawberries. Food and Bioprocess Technology, 7(10), 3045-3054. https://doi. org/10.1007/s11947-014-1356-0

24. Ziuzina, D., Misra, N.N., Cullen, P.J., Keener, K., Mosnier, J.P., Vilaró, I., Gaston, E., Bourke, P. (2016). Demonstrating the potential of industrial scale in-package atmospheric cold plasma for decontamination of cherry tomatoes. Plasma Medicine, 6(3-4), 397-412. https://doi.org/10.1615/PlasmaMed.2017019498

25. Rowan, N.J., Espie, S., Harrower, J., Anderson, J.G., Marsili, L., MacGregor, S.J. (2007). Pulsed-plasma gas-discharge inactivation of microbial pathogens in chilled poultry wash water. Journal of Food Protection, 70(12), 2805-2810. https://doi. org/10.4315/0362-028X-70.12.2805

26. Ehlbeck, J., Schnabel, U., Polak, M., Winter, J., Von Woedtke, Th., Brandenburg, R., Von Dem Hagen, T., Weltmann, K.-D. (2011). Low temperature atmospheric pressure plasma sources for microbial decontamination. Journal of Physics D: Applied Physics, 44(1), 13002. https://doi.org/10.1088/0022-3727/44/1/013002 27. Segat, A., Misra, N.N., Cullen, P.J., Innocente, N. (2016). Effect of atmospheric pressure cold plasma (ACP) on activity and structure of alkaline phosphatase. Food and Bioproducts Processing, 98, 181-188. https://doi.org/10.1016/j.fbp.2016.01.010 28. Li, Y., Kojtari, A., Friedman, G., Brooks, A.D., Fridman, A., Ji, H.-F. (2014). Decomposition of I-valine under nonthermal dielectric barrier discharge plasma. Journal of Physical Chemistry B, 118(6), 1612-1620. https://doi.org/10.1021/jp411440k

29. Wang, Y., Wang, Z., Yang, H., Zhu, X. (2020). Gas phase surface discharge plasma model for yeast inactivation in water. Journal of Food Engineering, 286, Article 110117. https://doi. org/10.1016/j.jfoodeng.2020.110117

30. Sahebkar, A., Hosseini, M., Sharifan, A. (2020). Plasma-assisted preservation of breast chicken fillets in essential oilscontaining marinades. LWT, 131, Article 109759. https://doi. org/10.1016/j.Iwt.2020.109759 
31. Laroussi, M. (2005). Low temperature plasma-based sterilization: overview and state-of-the-art. Plasma Processes and Polymers, 2(5), 391-400. https://doi.org/10.1002/ppap.200400078 32. Moisan, M., Barbeau, J., Crevier, M. -C., Pelletier, J., Philip, N., Saoudi, B. (2002). Plasma sterilization. methods and mechanisms. Pure and Applied Chemistry, 74(3), 349-358. https://doi. org/10.1351/pac200274030349

33. Weltmann, K. -D., Von Woedtke, T. (2011). Basic requirements for plasma sources in medicine. EPJ Applied Physics, 55(1), Article ap100452. https://doi.org/10.1051/epjap/2011100452

34. Azharonok, V.V., Kratko, L.E., Nekrashevich, Y.I., Filatova, I.I., Melnikova, L.A., Dudchik N. V., Yanetskaya S. A., Bologa, M.K (2009). Bactericidal action of the plasma of high-frequency capacitive and barrier discharges on microorganisms. Journal of Engineering Physics and Thermophysics, 82(3), 419-426. . https://doi.org/10.1007/s10891-009-0210-0

35. Laroussi, M., Tendero, C., Lu, X., Alla, S., Hynes, W. L. (2006). Inactivation of bacteria by the plasma pencil. Plasma Processes and Polymers, 3(6-7), 470-473. https://doi.org/ 10.1002/ ppap.200600005

36. Pestov V. V. Device for treating wounds and stopping bleeding using low-temperature atmospheric pressure plasma. Patent RF, no. 2732218C12019. (In Russian)

37. Fröhling, A., Durek, J., Schnabel, U., Ehlbeck, J., Bolling, J., Schlüter, 0. (2012). Indirect plasma treatment of fresh pork: decontamination efficiency and effects on quality attributes. Innovative Food Science and Emerging Technologies, 16, 381-390. https://doi.org/10.1016/j.ifset.2012.09.001

38. Jung, S., Lee, J., Lim, Y., Choe, W., Yong, H.I., Jo, C. (2017). Direct infusion of nitrite into meat batter by atmospheric pressure plasma treatment. Innovative Food Science and Emerging Technologies, 39, 113-118. https://doi.org/10.1016/j.ifset.2016.11.010
39. Arjunan, K. P., Sharma, V. K., Ptasinska, S. (2015). Effects of atmospheric pressure plasmas on isolated and cellular DNA - a review. International Journal of Molecular Sciences, 16(2), 29713016. https://doi.org/10.3390/ijms16022971

40. Bourke, P., Ziuzina, D., Han, L., Cullen, P. J., Gilmore, B. F. (2017). Microbiological interactions with cold plasma. Journal of Applied Microbiology, 123(2), 308-324. https://doi. org/10.1111/jam.13429

41. Kim, H-J, Yong, H.I., Park, S., Kim, K., Bae, Y.S., Choe, W., Jo, C. (2013) Effect of inactivating Salmonella Typhimurium in raw chicken breast and pork loin using an atmospheric pressure plasma jet. Journal of Animal Science and Technology, 55(6), 545549. https://doi.org/10.5187/JAST.2013.55.6.545

42. Zhang, M., Oh, J. K., Cisneros-Zevallos, L., Akbulut, M. (2013). Bactericidal effects of nonthermal low-pressure oxygen plasma on S. typhimurium LT2 attached to fresh produce surfaces. Journal of Food Engineering, 119(3), 425-432. https://doi. org/10.1016/j.jfoodeng.2013.05.045

43. Ulbin-Figlewicz, N., Jarmoluk, A., Marycz, K. (2015). Antimicrobial activity of low-pressure plasma treatment against selected foodborne bacteria and meat microbiota. Annals of Microbiology, 65(3), 1537-1546. https://doi.org/10.1007/s13213-014-0992-y 44. Ulbin-Figlewicz, N., Brychcy, E., Jarmoluk, A. (2015). Effect of low-pressure cold plasma on surface microflora of meat and quality attributes. Journal of Food Science and Technology, 52(2), 1228-1232. https://doi.org/10.1007/s13197-013-1108-6 45. Gök, V., Aktop, S., Özkan, M., Tomar, 0. (2019). The effects of atmospheric cold plasma on inactivation of listeria monocytogenes and staphylococcus aureus and some quality characteristics of pastırma - A dry-cured beef product. Innovative Food Science and Emerging Technologies, 56, Article 102188. https://doi. org/10.1016/j.ifset.2019.102188

\section{AUTHOR INFORMATION}

NataliaYu. Moskalenko - graduate student, Department of food engineering, Ural state University of Economics, 620144, Yekaterinburg, 8 March str., 62 .

Tel.: +7-912-244-40-22, E-mail: moskalenko_nu@usue.ru

ORCID: https://orcid.org/0000-0001-8204-9737

Olga A. Kudryashova - candidate of technical sciences, leading researcher, scientific laboratory of normative and technical developments and expertise, All-Russian Scientific Research Institute of Poultry Processing Industry - Branch of the Federal State Budget Scientific Institution Federal Scientific Center"All-Russian Research and Technological Poultry Institute" of Russian Academy of Sciences, 142552, Moscow region, Rzhavki township. Tel.: +7-903-687-62-17, E-mail: std@vniipp.ru

ORCID: https://orcid.org/0000-0002-6597-0492

Leonid S. Kudryashov - doctor of technical sciences, professor, chief researcher, V. M. Gorbatov Federal Research Center for Food Systems of Russian Academy of Sciences, 109316, Moscow, Talalikhina str., 26.

Tel.: +7-903-627-33-06, E-mail: 1skudryashov@yandex.ru

ORCID: https://orcid.org/0000-0001-5889-9176

Sergey L. Tikhonov - doctor of technical Sciences, professor, head of the Department of food engineering, Ural state University of Economics, 620144, Yekaterinburg, 8 March str., 62.

Tel.: +7-912-276-98-95, E-mail: tihonov75@bk.ru

ORCID: https://orcid.org/0000-0003-4863-9834

* corresponding author

Natal'ya V. Tikhonova - doctor of technical Sciences, docent, Professor of the Department of food engineering, 620144, Ural state University of Economics, Yekaterinburg, 8 March str., 62.

Tel.: +7-912-276-98-95, E-mail: tihonov75@bk.ru

ORCID: https://orcid.org/0000-0001-5841-1791

Vladimir V. Pestov - Head of the Research Coordination Department, FOTEK OOO, 620049, Ekaterinburg, Malysheva Street, 145A, liter A.

Tel.: +7-912-607-18-67, E-mail: nivatc@gmail.com

ORCID: https://orcid.org/0000-0001-5788-0633

All authors bear responsibility for the work and presented data.

All authors made an equal contribution to the work.

The authors were equally involved in writing the manuscript and bear the equal responsibility for plagiarism.

The authors declare no conflict of interest.

Received 28.12.2020 Accepted in revised 20.03.2021 Accepted for publication 25.03.2021 